\title{
The Finnish Abortion and Sterilization Situation and Family Planning Guidance According to the Public Health Law
}

Finland's first abortion law was enacted in 1950. Its main purpose was to decrease the number of illegal abortions. According to the indications it used this law belonged to the group of so-called socio-medical abortion laws. According to the law if life circumstances were especially difficult, they were taken into consideration in addition to medical indications when granting an abortion. The law was in force for 20 years. During this time the number of legal abortions remained quite low at first, even in 1965 it was still under 5000 . Apparently the number of illegal abortions was high, although exact figures are not available and estimates range between 4000 and 20.000. Attitudes toward the legal interruption of pregnancy gradually became more liberal and during the last year the law was in force over 8000 legal abortions were performed. The greatest weaknesses felt to exist in the first abortion law were first that getting a legal abortion depended considerably on where the person lived and secondly, people who belonged to the upper social classes had more possibilities to get an abortion than those from the lower classes, where the need for abortions was greatest.

The new abortion law came into force in 1970. In addition to the indications mentioned in the earlier law the new law contains three groups, namely social reasons, an enlargened age indication and a group of so-called socio-medical reasons.

Because the determination of social indications is difficult, the National Board of Health has sent the nation's physicians a circular letter containing directives for achieving uniformity. The National Board of Health lists such reasons as being unmarried, widowed, the loss of one's job, the interruption of one's studies and going into debt as sufficient reasons for granting an abortion, although in each case the decision should be made with due consideration. The enlarged age indication means that any woman under 17 or over 40 can get an abortion without having to make a request and so can any woman who has given birth to four children. The group of socio-medical reasons contains cases where illness, mental disturbance or a reason comparable to these seriously limits the ability of one or both parents to care for the child. In addition to the three groups of reasons mentioned above, an abortion can be granted on medical, eugenic or ethical grounds as in accordance to the earlier law. 
The abortion is performed at the woman's request, and cannot be performed after the 16 th week of pregnancy. In special cases the National Board of Health may grant permission to perform an abortion up to the 20 th week of pregnancy. In 1970 the average length of pregnancy at the time of the abortion was 10.8 weeks.

According to the earlier abortion law the National Board of Health appointed certain physicians to judge abortion requests. They were very few in number, altogether about 500. According to the new law every physician working for the State or commune is under obligation to handle abortion requests. These physicians number over 4000 . If the abortion is requested because of eugenic indications the National Board of Health makes the decision. If the case concerns an enlargened age indication the physician who will perform the abortion decides the matter. In the majority of cases the decision is made by two physicians.

Abortions are performed in the hospital. Out-patient clinic abortions have been performed only for experimental purposes in a few hospitals. All central and regional hospitals and other hospitals which have a maternity ward are obligated to perform abortions.

The effect of the new law on the number of abortions has been considerable. In 1969, under the former law, legal abortions amounted to 8175 or $122 / 1000$ births. In 1971 the respective figures were 20.622 and 336 . In 1972 the number of abortions rose further by about $10 \%$. At the same time the number of illegal abortions has decreased, although exact figures are not available. The number of abortions cared for in hospitals with cause unknown has decreased about $60 \%$.

The new abortion law has probably not had a great effect on the birth rate, for the birth rate has declined steadily throughout the sixties. In 1969 the birth rate was 14.3 and in 1971 it was 13.3. Apparently the law has decreased the use of contraceptives, although very few women use abortion a second time as a method of birth control. In $1970-71,96 \%$ of the abortions were first abortions, $3.5 \%$ were second abortions, $0.1 \%$ were third abortions, and for no one was it the fourth or more. The fact that the number of legal abortions has increased noticeably and the birth rate has declined only slightly must mean that illegal abortions have decreased.

During the period that the earlier law was in force there were great regional differences in the number of abortions. In the underdeveloped areas of Northern Finland the number of abortions per 1000 births was 22.3 in $1963-67$, while in Helsinki and its environs the respective figure was 146.8. In 1970 the respective figures were 163.6 and 411.5, although the new law had been in effect only six months. The differences had evened out somewhat but were still quite noticeable.

When the percentage of abortions in the different social classes are compared, there were great differences under the old law all over the country. Under the new law the greatest relative increase has taken place in the lowest 
class in the underdeveloped areas. However, the greatest number of abortions is performed on women from the middle social class. The average age of abortion patients in 1970 was 29.1 years; the percentage under 19 years of age was $13 \%$. The highest absolute frequency of abortions was among 20-24-yearolds. The most common grounds for abortion were medical and social reasons. Especially in the underdeveloped areas the number of abortions performed because of social indications increased under the new law.

The new sterilization law came into force in Finland at the same time as the new abortion law. Its purpose was to make it easier for people capable of serious deliberation to be sterilized and also to decrease the possibility that a person will come under pressure to be sterilized. According to the law sterilization is performed at the person's request, if there is a eugenic indication, if the person's illness or mental disturbance limits his ability to care for children, when the birth and care of children would cause the person considerable strain or if the person's chances to prevent the birth of children in any other way are unusually poor. Sterilization as a method of birth control is considered irreversible. Therefore, according to the sterilization statute, the significance of this measure must be carefully explained to the person concerned. If marriage partners are concerned, they must see the physician together to decide which spouse it would be more convenient to sterilize.

If there is a medical indication, a woman can be sterilized after a decision by the physician judging request who has been named by the National Board of Health and the physician who will perform the operation. In all other cases the request for sterilization must be sent to the National Board of Health. All male sterilizations are also handled by the National Board of Health. Sterilization is performed on women via laparotomia and the procedure requires a week's stay in the hospital. A vasectomy is performed on men in an out-patient clinic.

The number of sterilizations has increased somewhat under the new law. In 1967 a total of 4022 sterilizations were performed and in 1970 the respective figure was 5727. While the old law was in force, $30 \%$ of all abortion patients were sterilized in connection with abortion. In 1970 the respective figure was $16 \%$. Under the old law 20-40 male sterilization requests were handled a year by the National Board of Health. In 1971 there were 582 requests. Only $0.2 \%$ of these requests were denied.

In order to decrease the number of abortions in Finland much emphasis has been given to intensifying preventive means of birth control. In 1972 the public health law came into force, according to which the duties of a health center include intensifying health education, which also includes giving out information on contraception. The aim is to help people in their efforts to prevent unwanted pregnancies, help people time their pregnancies the way they wish and to guide people in preventing the need for the interruption pregnancy by using effective methods of birth control. Birth control guidance is aimed at the sexually mature population of each area. 
Up till now Finland has had a separate network of maternal and child care clinics which have encompassed about $99 \%$ of all expectant mothers and children. The purpose of the public health law is to get people to turn to the local health worker also in matters concerning family planning. Every citizen has the right to receive free guidance in birth control at the local health center. The first step is a conference with a district nurse. Then an appointment is made for the person with a health center physician for either getting birth control pills or an intrauterine device. Health centers also distribute other contraceptives free-of-charge.

In addition to private guidance, health centers are also charged with the dispensing of general information in their area. The staff of the health center must be active in arranging general information meetings and group guidance concerning contraception. These should be arranged above all for groups already in existence like school children at an appropriate age, parents receiving birth preparation and young men in the military. Health center nurses and physicians must act in the role of specialists at meetings and talks possibly arranged by different organizations or schools.

One diffuculty in carrying out the law is the lack of sufficiently trained personnel. Nurses receive further education in the form of courses that also contain lectures on family planning. Health center physician are trained at central hospitals in, among other things, how to insert intrauterine devices.

Attitude change among the citizens can be considered another prerequisite for carrying out the law. Organized sex education is beginning in the basic school. Program series on family planning are being presented on TV and radio. Periodicals are yet another channel that distribute information on contraceptive methods and voluntary organizations distribute free booklets on birth control.

\section{References}

Härö, A. S. and Koskela R.: Laillisten raskaudenkeskeytysten viimeaikaiset kehityssuunnat Suomessa. Sosiaalinen aikakauskirja 5:1971.

Kettunen, I.: Nykyisestä aborttilaista ja sen soveltamisesta. Suomen Lääkärilehti 26: 1813: 1971.

Lahti, R.: Perhesuunnittelupolitiikka ja syntyvyyden säännöstelyä koskeva lainsäädäntömme. Oikeus 1: 15: 1972 .

Lahti, R.: Uusien abortti- ja steriloimislakien vaikutus maassamme. Suomen Lääkärilehti 28: 303: 1973 .

Lääkintöhallituksen kirjelmä DN.o 10868/09/1972. Liite A. 